\title{
ACTIONS AND CAUSES OF ACTION
}

\author{
O. L. MCCASKILI
}

When the New York Commissioners on Practice and Pleadings substituted the one form of civil action for the separate actions at Iaw and suits in equity they did not succeed in establishing a system free from procedural difficulties. One court, with jurisdiction in law and equity, was necessarily more complex than either a law or equity court functioning separately. While it was possible to continue two distinct systems of administration in the one court the Commissioners were persuaded that they were charged with the duty of formulating a single scheme. ${ }^{1}$ They declared that they intended to create, ${ }^{2}$ and most scholars are agreed that they did create, a blended system, but the manner of the blending and the strength of the respective strains is still the subject of much disagreement. After three quarters of a century the one form of civil action is still an elusive concept. It has not been enough for us to know that an action is an ordinary prosecution in a court of justice by one party against another for the enforcement or protection of a right, the redress or prevention of a wrong. All too frequently the prosecution has become so confused, because of the inability of the courts to understand the nature of the blended system under which it was brought, that rights have been sacrificed and wrongs perpetrated. In seeking to evade one technicality they have created another of far more serious import. ${ }^{3}$ A code section has made provision for joinder of causes of action. Other sections provide for joinder of parties. The relation of the cause of action to the action, on the one hand, and to the parties, on the other, has proved most perplexing. The cause of action has not been understood. Eminent writers on the code have failed to agree as to its character and scope. It is the object of this article to point out some features of the blended system centering around the relation between the action and the cause of action which seem to have escaped observation, with the hope that the nature of the cause of action as a distinct procedural unit may be more clearly understood, and the desired flexibility in the action attained without interfering with substantial rights.

In describing the cause of action Mr. Pomeroy says :4

\footnotetext{
1 First Report of the Commissioners on Practice and Pleadings, N. Y. I848, 145, I46, hereafter referred to as First Report.

${ }^{2}$ Ibid. I45.

'Hahl v. Sugo (IgoI) I69 N. Y. 109, 62 N. E. 135, where a defendant was given perpetual occupancy of plaintiff's land because plaintiff fell into the procedural pitfall of splitting the new kind of cause of action created by the court. This case is fully discussed infra, note 65 .

- Pomeroy, Code Remedies (4th ed. I904) secs. 347-349.
} 
"Every judicial action must therefore involve the following elements : a primary right possessed by the plaintiff, and a corresponding primary duty devolving upon the defendant; a delict or wrong done by the defendant which consisted in a breach of such primary right and duty; a remedial right in favor of the plaintiff, and a remedial duty resting on the defendant springing from this delict, and finally the remedy or relief itself. Every action, however complicated or however simple, must contain these essential elements. Of these elements, the primary right and duty and the delict or wrong combined constitute the cause of action in the legal sense of the term, and as used in the codes of the several States. They are the legal cause or foundation whence the right of action springs, this right of action being identical with the 'remedial right' as designated in my analysis. In accordance with the principles of pleading adopted in the new American system, the existence of a legal right in an abstract form is never alleged by the plaintiff; but, instead thereof, the facts from which that right arises are set forth, and the right itself is inferred therefrom. The cause of action, as it appears in the complaint when properly pleaded, will therefore always be the facts from which the plaintiff's primary right and the defendant's corresponding primary duty have arisen, together with the facts which constitute the defendant's delict or act of wrong..... From one cause of action, that is, from one primary right and one delict being a breach thereof, it is possible, and not at all uncommon, that two or more remedial rights may arise, and therefore two or more different kinds of relief answering to these separate remedial rights. This is especially so when one remedial right and corresponding relief are legal, and the other equitable; but it is not confined to such cases..... If the facts alleged show one primary right of the plaintiff, and one wrong done by the defendant which involves that right, the plaintiff has stated but a single cause of action, no matter how many forms and kinds of relief he may claim that he is entitled to, and may ask to recover; the relief is no part of the cause of action."

Judge Bliss says: 5

"We have defined an action to be a judicial proceeding for the prevention or rediess of a wrong. The 'cause of action', then, is the 'wrong'.... There can be no cause of action aside from the facts which constitute it ... The facts show a wrong committed or threatened, and unless they do, there is no cause of action... The wrong may be done [or the cause of action may arise] by the denial of a right; or by the refusal to respond to an obligation; or it may arise from mere neglect in the performance of a duty; or it may be an affirmative injury... The cause of action and the facts which show it involve, then, some wrong suffered by the plaintiff-some infraction of his rights... The law may give more than one kind of relief for a single wrong - that is, for a single cause of action."

He follows with several illustrations where the facts, in his judgment, show a single wrong, and, therefore, a single cause of action, but give rise to cumulative or optional remedies.

Judge Phillips describes the cause of action in this fashion:6

Bliss, Code Pleading (3d ed. I824) secs. II3, II4.

- Phillips, Code Pleading (I896) secs. 30-32. 
"The question to be determined at the threshold of every action is, whether there is occasion for the state to interfere. Therefore, when a suitor asks that the public force be exerted in his behalf, he must show that there is, prima facie, occasion for the state to act in his behalf. That is, he must show a right in himself, recognized by law, and a wrongful invasion thereof, actual or threatened. And since both rights and delicts arise from operative facts, he must affirm of himself such investitive fact or group of facts as will show a consequent legal right in him, and he must affirm of the adversary party such culpatory fact or facts as will show his delict with reference to the right so asserted. The formal statement of operative facts showing such right and such delict shows a cause for action on the part of the state and in behalf of the complainant, and is called in legal phraseology, a cause of action."

"From the foregoing definitions of right of action and cause of action, it will be seen that the former is a remedial right belonging to some person, and that the latter is a formal statement of the operative facts that give rise to such remedial right. The one is matter of right, and depends upon the substantive law; the other is matter of statement, and is governed by the law of procedure."....

"It will appear, without further analysis, that a statement of facts, to constitute a cause of action, must show a right of action; that to show a right of action, it must state facts to show (I) a primary right and its corresponding duty, and (2) the infringement of this right by the party owing this duty. From the one set of facts the law raises the primary right and duty, and to the other set of facts the law attaches a remedial right, or right of action....

"From one right of action,-that is, from one primary right and one breach thereof,- - may arise a right to two or more different kinds of relief, obtainable in one action. In such case there being but one right of action, there should be but one cause of action stated in a complaint asking for several kinds of relief." " . . .

"A complaint should state a separate cause of action for each right of action disclosed by the facts therein stated; and whatever facts would, if stated by themselves, entitle one to relief by action, constitute a right of action, and should be separately stated as one cause of action. In determining whether a given statement of operative facts, investitive and culpatory, discloses but one right of action or more than one, it is necessary only to determine whether more than one primary right has been invaded, or whether there has been more than one invasion of a single primary right. Leaving out of consideration the nature or kinds of relief sought, if but one right, however comprehensive, is asserted, and if but one delict, however complex, is complained of, but one right of action is disclosed. If the facts disclose more than one distinct primary right of the plaintiff, and invasion thereof by the defendant, whether by one delict or by several; or if there are disclosed two or more distinct invasions by the defendant, of a single primary right of the plaintiff, more than one right of action is disclosed, and these should be separately stated."

Emphasis is the chief point of difference between these authors. Judge Bliss puts emphasis on the element of wrong, but he uses the

${ }^{7}$ Ibid. sec. 2 ro.

Ibid. sec. 438 . 
term "wrong" in a comprehensive sense, embracing the element of "right." His analysis makes it clear that not only does he recognize that there can be no wrong without a corresponding right, but that these elements are so bound up with each other that it is impossible to describe a wrong without also describing the right which has been wronged. Judge Phillips makes the importance of the fact element much clearer than either Mr. Pomeroy or Judge Bliss, and brings out that the same facts which give the individual a right to appeal to the state through the courts for relief, when stated, and only when stated, give the state cause for action on his behalf. The unstated facts give a "right of action," but the stated facts give a "cause of action." He complains ${ }^{2}$ that Mr. Pomeroy uses these as equivalent and interchangeable terms, which he says is inaccurate and tends to obscure where clearness of conception and perspicuity of statement are most essential. While it must be admitted that Mr. Pomeroy emphasizes the plaintiff's primary right as one important element in the cause of action, he likewise excludes the plaintiff's remedial, or secondary right. ${ }^{10}$ The plaintiff's right to sue is not his cause of action. While Mr. Pomeroy speaks of the cause of action as being composed of a primary right and a delict, no careful and fair minded reader can fail to discern that he means the facts which give rise to the right and the facts which constitute the delict.11 While he puts the emphasis on the plaintiff's cause for acting (having a right to act), there can be no mistake that his text is likewise dealing with the state's cause for acting on his behalf, based upon his statement of his cause. In emphasizing operative facts Judge Phillips, equally with Mr. Pomeroy, points out that they must have investitive and culpatory features, must be such as relate themselves to rights and wrongs. Just facts, colorless facts, whether stated or unstated, do not enter into the analysis of any of these writers. All are in agreement that the character and scope of a single cause of action cannot be determined from the nature or number of reliefs sought; that a single cause of action may give rise to a number of different reliefs. In making the scope of a cause of action to depend upon the existence of facts showing but one right and one wrong, none of them offers any helpful suggestion as to how the singleness of rights and wrongs is to be determined.

In a recent article Professor Clark has severely arraigned the "primary right and duty and the delict or wrong" test of the cause of action.

He says: $\mathbf{: 1 2}^{12}$

"This, too, makes the cause of action include law and not merely facts contrary to the idea of the codifiers; and further it is pointed

'Ibid. sec. 3I, note.

${ }^{20}$ Pomeroy, op. cit. supra note 4 , sec. 348.

11 Ibid. sec. 347, concluding part.

${ }^{12}$ Clark, The Code Cause of Action (1924) 33 Yale Law Journat, 817, 826. 
out that there is no real delict in such actions as those for partition or for probate of a will. Perhaps the most direct of all the criticisms is that it is hard to see what the definition means. Like the code itself, it seems to be precise, and yet upon application in practice it does not carry any exact meaning which will afford any practical test for the problem to which it should afford the solution. The definition is itself a mixture in which fact and law, operative facts and legal relations, are intertwined... The net result in practice is that the primary right, which is apparently thought of as a simple and precise thing, turns out to be complex and indefinite. It means what the person using the term makes it mean."

Professor Clark finds the best approach to a solution in a recognition of the distinction between operative facts and legal relations, which he says is beautifully worked out by Judge Phillips in the first part of the quotation above taken from his work. He disagrees with this author that a statement can be a cause of action, declaring that at this point he has fallen into a slight error, and asserts that the cause of action is the group of operative facts giving cause or ground for judicial interference. More fully he defines the cause of action as follows: $:^{13}$

"An aggregate of operative facts which give rise to one or more relations of right-duty between two or more persons. The size of such aggregate should be worked out in each case pragmatically with an idea of securing convenient and efficient dispatch of trial business."

Like the authors already quoted, he negatives the possibility of the kind or number of reliefs to which a party is entitled or which he seeks being a factor in determining the scope of the cause of action, and severely criticizes cases and notes upon cases which try to make use of this element. He makes the startling statements that the term "cause of action" did not become a term of art in connection with joinder problems in pleading until the adoption of the code, ${ }^{14}$ and that in working out the details of the pleading reform the code commissioners attempted to employ a technique based upon the utterly inconsistent principles of equitable flexibility and inelastic certainty. ${ }^{15} \mathrm{He}$ finds a delightful air of preciseness in the code terms, but complains that in fact they are vague and general, and that the certainty is somewhat elusive. Unless construed in the light of a purpose they are meaningless. This purpose he finds to be the convenient, economical

\footnotetext{
${ }^{23}$ Ibid. 837 .
}

14 Ibid. 820 .

${ }^{15}$ Ibid. 817. This criticism seems to be unwarranted, and is based on the hypothesis that there is no sound middle ground between extreme flexibility and extreme certainty. It likewise ignores the possibility and desirability of rigidity at some points and flexibility at others. In the sections used as illustrations it is easy to see generality and flexibility in the terminology, but the delightful air of preciseness is difficult to discover. Professor Clark's discussion shows merely a conflict between interpreters, not a confused conflict of purposes in the authors of the code. 
and efficient conduct of court business, and the enforcing of rules of substantive law with as little obtrusion of procedural rules as possible. On behalf of his definition he says : ${ }^{\mathbf{1 6}}$

"It may be objected that here is no absolute definite definition, no mathematical test to be applied as a rule of thumb. None such is intended or thought feasible. There is no royal road to pleading for either bench or bar. Two things, however, are claimed for this analysis. First, it puts the emphasis where it should be, namely, on the operative facts. Our problems of joinder, of stating a cause, of amendment, should be decided with reference to the.ease of developing the operative facts in our law trials, and our application of legal principles to such facts when developed may be expected to take care of itself. Second, it affords a test or touchstone for extending or limiting our view to meet the exact situation presented in each case..... This would leave a considerable choice to the pleader himself, but still more it would leave much to the discretion of the trial judge, who. after all is the one upon whom the responsibility of getting trial work done must rest."

It is doubtful if Professor Clark has been able to avoid the faults pointed out in others. His description of the cause of action is attractive but elusive. It is a group of operative facts within the action, a procedural concept, but when he begins to characterize these facts as those which give rise to one or more relations of right-duty, he is relating them to rules of law, and, like Pomeroy, to that extent, constructing a definition which is a mixture of fact and law, operative facts and legal relations being intertwined, with the net result that it means what the person using the term makes it mean, and each trial judge, guided only by the principle of administrative convenience, shapes the cause of action to meet his own ideas. The definition does not require the presence of operative facts showing a delict. In pointing out the fact that it is difficult to find a delict in an action of partition or the probate of a will (he might have added actions to construe wills, to perpetuate testimony, condemnation proceedings, etc.) he fails to take cognizance of the comparatively small number of actions of this kind, and attempts to construct a definition to fit them, ignoring the delict element in the great majority of actions. The definition embodying facts showing the delict element may not be universal, but it approximates universality, whereas his definition cannot, at best, apply to more than a small minority of the actions. In justice to Professor Clark it should be said that his definition is not a fair summation of his article, and that he does intend to include within it all of the operative facts necessary to call for judicial interference. It is indefinite, however, what he intends these shall be. The right-duty relations may be one or more, but when sufficient operative facts are stated to establish one right-duty relation, and when they reach the point of establishing another such relation, is not indicated. The right-duty relation, like the primary right, is somewhat abstract.

${ }^{26}$ Ibid. 830. 
We are certain to be impressed with the aim of administrative convenience stressed by Professor. Clark. Likewise we should be sympathetic toward that amount of flexibility in the action which will make it possible to attain this aim. But flexibility may be carried to such an extreme that our procedural machine will have no stability. Every connection in it cannot be a universal joint if it is to be a vehicle to carry us to an expected destination. Leaving to the trial judge the fixation of the scope of the cause of action does not make for administrative convenience. It ignores one of the most useful purposes of the cause of action as a procedural unit in the action. It ignores the function of a pleading as an instrument of preparation for the trial. It proceeds upon the false assumption that a pleading properly partitioned.in advance of trial can prove of no aid to parties or trial judge. It assumes that the average trial judge, with a heavy calendar of jury cases, has ample time to think, and that, with lightning-like rapidity and a fair degree of accuracy, he can untangle on the trial all the facts set forth in the pleading, however complicated, see each rightduty relation clearly and instantly, rule on the materiality of evidence with precision, and, in his charge to the jury, group together those principles of law which relate to certain facts only. It in truth rests upon that pertinent statement made by him: $:^{17}$

"Our application of legal principles to such facts when developed may be expected to take care of itself."

My experience in the observation of trial practice leads me to the belief that legal principles do not readily apply themselves however well the operative facts may come out on the trial; that jury trials consist of something more than merely getting the facts to the jury with the least possible amount of judicial machinery; that judges, particularly under an elective system, are variable in their abilities, and a successful administrative system must be brought down to the level of at least the average judge; that the judge is pressed for time, and can function more efficiently if the task of grouping facts according to the legal principles which attach to them is done in advance for him. The greater the number of operative facts brought into the single suit the greater is his need for mechanical aid in marshalling them before the jury. Complaints are made against the effectiveness of the jury, the irritation frequently manifesting itself in judicial decisions curtailing this mode of trial, but we cannot expect to improve the effectiveness of the jury by rushing to it half baked and undigestible facts. Half baked and undigestible they are sure to be if the legal principles applicable to them, are left to be self applied. The effectiveness of our trials cannot be determined altogether by the speed and ease with which results are obtained in the trial coturt. We may discover some surprising things when we note the number of appeals,

${ }^{27}$ Ibid. 831 . 
and the number of complaints on appeal to rulings on evidence and charges of the court to the jury, complaints which all too frequently are well founded. Some of these mistakes are undoubtedly ascribable to deficiencies in the trial judge, for fallible they will always be, but I am confident that many of them are the result of overtaxed judges, who have been asked to do the impossible. The problem of simplifying procedure is more than a problem of elimination. Pleadings may be made so simple, in the interest of the pleader and his client, that they cease to serve any useful purpose. Unfortunately legal scholarship in the field of procedure seems to have been affected by that insidious and malignant poison "make it easy." The antidote "make it thorough" is badly needed. Effective elasticity in the action is not obtained by making the bundles of facts presented to juries elastic within themselves, but by making it possible to bring together within the action a greater number of small bundles of definite character.

In the preceding paragraphs I have pointed out that each of the writers mentioned, properly understood, defines the cause of action as a group of operative facts which must show grounds for judicial action on behalf of the complaining party or parties, and that each of them insists that the scope of the cause of action must be determined without reference to the remedy or remedies sought. In coming to the latter conclusion they have been influenced, perhaps, by the character of the equity suit, and by the fact that the code commissioners undoubtedly intended to carry into the new system many features of the equity practice. ${ }^{18}$ They seem to have overlooked the fact, however, that this new system also retained many features of the common law practice. To them the equity strain in the blended system has been the predominant and controlling factor. In my judgment they have overworked this feature.

Constitutions have preserved the right of trial by jury where it was enjoyed before the codes. For the purpose of determining the mode of trial it is as essential now as then to determine the nature of the facts to be tried. The commissioners recognized and made provision for this. In bringing the law action and the equity suit under one general scheme of procedure they did not destroy the essential characteristics of each. They merely adopted one scheme comprehensive and flexible enough to deal with either singly or with the two in conjunction. In abolishing the distinctions between law actions and equity suits they did not abolish law actions and equity suits. By abolishing the distinctions between the forms of law actions they did not convert an action for a breach of contract into one to obtain possession

${ }^{18}$ The other influence, the code provision that the complaint contain a demand for the relief plaintiff supposes himself entitled to, incorrectly interpreted to mean that the correct relief in no way characterized the cause of action, is dealt with later. 
of land. The same kind of reliefs are given under the new as under the old system. Each is distinct from the other, founded upon different operative facts, and calling for the application of different rules of law. The barriers developed under the old systems which prevented many of these remedies from being administered in a single suit in one court were distinctive to the separate system. It was desirable that these distinctions cease, and they were abolished. The equity suit was tried upon depositions taken out of court, whereas law actions were tried upon testimony taken in open court. The equity bill was so framed as to require the defendant to make discovery. The common law declaration had no such feature. Equity pleadings stopped with a formal replication to the answer. At common law they proceeded through the rejoinder, sur-rejoinder, rebutter and sur-rebutter. At common law only such parties came into the action on one side as stood in a joint relation. In equity there was no such rigid requirement, a principle of administrative convenience controlling joinder and severance. Pleading fictions and making feigned issues was common in the law courts but unknown in equity. Pleading common counts and general issues permitted plaintiffs and defendants alike to conceal the real nature of the matters they were bringing into court in law actions. Nothing parallelled this in equity. The commissioners saw no virtue in retaining these and other distinctions. They adopted the common law methods of alleging facts in pleadings and making proof on trial, preserving the deposition only for those occasions when presence of the witness in court was impracticable, and providing a new means of obtaining a discovery. They cut off all pleadings beyond the replication in all actions. They made the equity rules as to joining parties applicable to all suits. They sought to do away with fictitious pleadings, common counts and general issues substituting a plain and concise statement of the facts without unnecessary repetition, and specific denials. ${ }^{19}$ As it is not necessary in order to have a MochaJava blend of coffee that every coffee bean be a hybrid mixture of Mocha and Java, so it was not necessary in order to have a law-equity blend of procedure that every unit in the system should have both characteristics.

If jury trials were to be preserved in actions of a legal nature it was essential that they be not so commingled with equity suits that their identity should not be determined. If different rules of law were to be applied to the different remedies administered under the one system, it was desirable that the facts calling for the different remedies,

${ }^{29}$ That only those distinctions which prevented the various remedies from being administered in one court under one harmonious system, and of the type mentioned, were intended to be abolished, and that abolition of distinctions was effected by adopting features from each of the old systems, is evident from the langtiage of the First Report, op. cit. supra note $r$. Reference is made to the following pages: $68-77,88,124,138,140,142,145,147$, I77. 
particularly if they were triable by untrained juries, should be separately grouped. A feature of the common law system of grouping these facts into counts within the declaration was thought worthy of preservation. $^{20}$ The code requirement that causes of action be separately stated, is nothing but the common law requirement that each cause of action be set out in a separate count.

Professor Clark is unquestionably mistaken in asserting that the cause of action as a term of art in connection with joinder problems was unknown before the codes. ${ }^{21}$ Though he admits there were rules of common law concerning the joining of actions, founded upon their character and their pleas and judgments, he sees no similarity between this practice and joining causes of action under the code. He points

${ }^{20}$ There may be evidence of a change of opinion of the Commissioners as to the value of the common law count. In their First Report, op. cit. supra note $I$, in condemning certain formalities of the common law system of pleading, and particularly features designed to produce singleness of issue, but which were declared not to have that result, they referred to the statute of Anne, permitting defendant to have as many pleas as he desired (p. 140), and to the abuses of the count system (p. I43). They expressed the opinion that disentangling the questions and separating those of fact and law was rarely accomplished by the common law system of pleading, and could not be done so long as ultimate instead of evidentiary facts were pleaded (p. I44). They put emphasis on the straightforward and natural story of events, declaring that if pleadings were all to be verified, as they intended, a system of pleading must be substituted which enabled parties to state the facts truly both in the cause of action and defense (p. 145). Despite this apparent criticism of common law partitioning methods they inserted in their code this section :

"Sec. 129. The defendant may set forth in his answer as many grounds of defense as he shall have. They shall be separately stated, and may refer to the causes of action which they are intended to answer, in any manner by which they may be intelligibly distinguished." (Italics are mine.) -

Here is not only a separation of facts according to association with legal principles, departing from the simple story, but authority to plead according to legal theory. No provision for separately stating causes of action in the complaint was made in this first code (p. I57). How the separate defenses would be made to refer to the appropriate causes of action if they were not separately stated does not appear, nor is it made to appear how a separate defence could apply to a simply told story unrelated to legal principles in its scope. Whether intentional or inadvertent the failure to make the separate statement applicable to the complaint was corrected by them in their Final Report of Dec. 3I, 1849 (p. 278).

Personally $I$ am inclined to think there was no change of view, and that the omission from the first code was inadvertent. The criticisms were directed to iseless formalities and abuses, not to all form, nor to counts properly restricted. Within the separate statements the story might be simple and straightforward, freed from legal verbiage. The references to the failure of the common law system to disentangle facts from law were directed to the production of an issue through extended pleadings beyond the answer, and not to the count system. Whether "disentangling" is desirable depends upon the idea intended to be conveyed by the word. This article contends for no other disentangling than such as will enable us to see the association between facts and law, and the interplay between them.

${ }^{2}$ Supra note 12, at p. 820 . 
with assurance to the opening paragraph of the section on joinder of causes of action:

"The plainiff may unite in the same complaint two or more causes of action, whether they are such as were formerly denominated legal or equitable, or both," etc.,

and argues that the language "formerly denominated" means that they no longer exist. ${ }^{22}$ His argument is self destructive. Not only does it admit, what he previously denied, that causes of action existed before the code, and that they were then called legal and equitable causes of action, but that these units, whether under old or new names, are to be joined under the new system and form a part of the code action. There is no intimation of any change in these units except in their names. It is also interesting to note that the language "whether formerly denominated," etc., did not come into the code until the amendment of $185^{2}$, when, for the first time, express provision was made for joining legal and equitable cause of action. ${ }^{23}$

A studying of the codes of 1848,1849 , and $185 \mathrm{I}$ throws some light on the nature of the cause of action. The sections on joinder of parties, based upon equity principles, not only in these early codes but subsequently, remained unchanged. If there was any intent to deal with joinder of causes of action under them it was not made manifest, and the fact that a separate section dealt specifically with this problem tends to show there was no such intent. However closely related the problems may be, the commissioners evidently thought that distinct concepts were involved, requiring separate treatment. Looking to the sections on joinder of causes of action, as constituted before the amendment of 1852 , we find they had a distinct legal character. Though no mention is made in them of common law actions, any one familiar with such actions would see that within the first classification was grouped the subject matter of actions of debt, assumpsit and covenant. In the code of $1848^{24}$ he would see in the second class trespass; in the

${ }^{22}$ Supra note 12, at p. 825 and note 47.

${ }^{23}$ N. Y. Laws, 1852 , ch. 392 , sec. 167 .

${ }^{24}$ Sec. 143 of the Code of 1848 reads:

"The plaintiff may unite several causes of action in the same complaint, where they all arise out of,

I. Contract, express or implied; or,

2. Injuries by force, to person or property; or,

3. Injuries without force to person or property; or,

4 Injuries to character; or,

5. Claims to recover real property, with or without damages, for the withholding thereof; or,

6. Claims to recover personal property, with or without damages for the withholding thereof; or,

7. Claims against a trustee by virtue of a contract or by operation of law.

But the causes of action, so united, must all belong to one only of these classes, and must equally affect all the parties to the action, and not require different places of trial." 
third case for negligence; in the fourth case for defamation; in the fifth ejectment; in the sixth replevin; in the seventh assumpsit, debt, covenant or account against a trustee. The section was utterly unsuited to actions of an equitable nature, and there is not the slightest evidence that it was intended to apply to such actions. The evidence is the other way. Not only was it impossible to combine groups of facts falling within one class with those in another class, which is a wide departure from equitable principles, but it was required that the causes of action joined should each affect all the parties to the action, a distinctive feature of common law actions. Looking at the groupings more carefully we find that contract subject matter cannot be joined with tort subject matter, strangely enough a rule which existed in the common law courts. Getting more specific, subject matter involving force cannot be joined with subject matter involving an absence of force, in other words, trespass and case cannot be joined. Nor can trespass be joined with ejectment or ejectment with replevin. Common law rules have been departed from in permitting all the contractual actions to be joined, in severing defamation from other actions in case, and in classifying separately the contract actions against trustees, but that the main divisions are shaped on common law lines, and deal with common law subject matter, is apparent. ${ }^{25}$ It is also apparent that the scope of a cause of action arising out of the common law subject matter can, in no case, extend beyond the limits

${ }^{25}$ I cannot agree with Professor Clark that the common law rules for the production of an issue did not call for the development of the idea of a cause of action, and that the tests of joinder of actions at common law were unrelated to the nature of the subject matter of the action. The nature of the subject matter determined the nature of the writ originally, but in the hands of clerks in the chancery, writs determined the nature of subject matter. Actions were of the same general nature only when they fell under the same class of writs, and were capable of being brought under one writ. Assumpsit, debt and covenant were not of the same general nature, though all were founded on contracts. Although in course of time the individual writ, containing such claims as could be brought within it, ceased to be the source of the court's jurisdiction to proceed, the dividing influence of the writ had left its imprint. Joinders remained as before. As writs had disappeared new reasons came to be invented for expressing the old jurisdictional boundaries. Emphasis was now put on forms of pleas and judgments, with some mention of the character of the action. The artificial rules were more difficult to state than to apply, for they were based on the old precedents, at times when detinue was debt in the detinet, and trover was case. Tidd seemed to appreciate that after all the writ test was the test of joinder. I Tidd; English Writs ( 1807 ) Ir.

It was the cause of action to which defenses were directed, and without the concept of a cause of action no issue could have been formed. The materiality of issues, whether there was a departure or not, was determined with reference to the cause of action, which was of the same or smaller scope than the writ, depending on whether the writ was issued on one or more causes of action falling within the class. 
of one class, but that, on the other hand, there may be many causes of action within a single class.

As in equity the joinder of parties necessarily involved the joining of operative facts warranting the presence of the various parties in the suit, it might be thought by one unfamiliar with the operation of the equity courts that the joinder of these various groups of operative facts constituted a joinder of equitable causes of action, and that the code section on joinder of causes of action failed to make provision for this. ${ }^{28}$ The code commissioners, because of their intimate knowledge of workings of the equity courts, made no such mistake. They knew that as a term, of art in connection with joinder problems the cause of action was limited to common law actions, and that only loosely and in a non-technical sense was it used in connection with joinders in equity. They knew that when parties who might proceed separately in equity in fact joined, they were thereafter considered as having several interests in one comprehensive group of operative facts, to which single group they gave the name "subject of action," interchangeable with "subject matter of the action." The parts of this comprehensive group of operative facts showing the rights of the several parties to their respective reliefs were not, after such joinder, treated as separate causes of action for purposes of pleading or trial. There was no occasion for such a separation to continue within the action. The trier of fact and trier of law were centered in one individual, a trained jurist. During the trial no panel of jurors was being detained from their usual pursuits. Time was not, relatively speaking, an important factor. The count system of the common law courts, if not a product of, was certainly adapted to jury trials. It did not obtain in equity except in those cases of an exceptional char-

${ }^{26}$ This was the confused idea in the mind of Judge Comstock in $N . Y . \& N . H$. R. R. v. Schuler (I858) I7 N. Y. 592, 604. His discussion shows a failure to appreciate the distinction between joinder of parties in equity and joinder of causes of action at law. Though he professes to base his ruling on the amendment made to the section on joinder of causes of action in 1852 , his subsequent discussion shows he in fact based it on the old equity rules as to joinder of parties, fully covered by the code sections on joinder of parties before that amendment.

We appreciate the distinction between the problems of joining parties and joining causes of action only when we see that every party in an equity suit, however several his interests might be, had certain subject matter related to him if he sought relief, or relief was sought against him, yet these different groups of subject matter were not, as at law, regarded as distinct causes of action after the joinder. Of course they would be separate causes of action, even in equity, if several suits could be and were brought on them. Because of this possibility they were sometimes loosely referred to as different causes of action joined in equity, but their distinct character was before, not after the joinder.

${ }^{27}$ I trace the origin of this term to such cases as Brizkerhoff $v$. Brown (I8z2, N. Y.) 6 John 139 , in which there is frequent use of the words "subject of the suit" The term is more fully explained infra. Cf. also Story, Equity Pleadings (roth ed. 1892). sec. $76 \mathrm{c}$, note 2 . 
acter where the jury was used in an advisory capacity. In these cases the issues to be tried by the jury were separately stated in advance of trial. ${ }^{28}$ These separate statements were not, so far as I have been able to discover, called counts, but in essence that is what they were, and their use centered around the jury.

We now have the explanation of the distinct sections on joinder of causes of action and joinder of parties. The section on joinder of causes of action did not deal with equity cases. The sections on joinder of parties provided for all joinders in equity of subject matter as well as of parties, but as applied to law cases could apply only to joinder of parties interested in a single cause of action. If parties interested in more than one cause of action were joined, immediately the tests applied by the section on joinder of causes of action must be applied. ${ }^{29}$ Thus construed the sections were in perfect harmony. There were still law actions and equity suits, with different provisions for the constitution and trial of each, but these different provisions for different things were brought together in one harmonious scheme operating in a single court.

In I852 a change of a very marked character was made in the section on joinder of causes of action. ${ }^{30}$ A new class was created, consisting of causes of action arising out of "the same transaction, or transactions connected with the same subject of action," and the opening paragraph was extended so as to provide for joining in the same complaint several causes of action "whether they be such as have been heretofore denominated legal or equitable, or both." ${ }^{31}$ At the same time, and by the same bill, that this amendment was made, the counterclaim section was added to the code. It provided that a counterclaim must be, among other things:

"I. A cause of action arising out of the contract or transaction set forth in the complaint as the foundation of the plaintiff's claim, or connected with the subject of the action;" or

\footnotetext{
${ }^{2 s}$ For the origin of the practice of framing issues for juries in equity see, 3 Blackstone, Commentaries, 452; Am. Dock \& Imp. Co. v. Trustees (I883) 37 N. J. Eq. 266, 269.

${ }^{20}$ In the code of I848 the test was that every cause of action joined must equally affect all the parties to the action, the common law rule. In 1849 the word "equally" was dropped, making it possible for a court so inclined to hold that the common law rule had been abandoned for the more liberal equity rule permitting parties differently affected to be joined in an action. The legislature may already have been looking forward to the more radical amendment of 1852, bringing legal and equitable causes of action together in the same suit, separately stated. A liberal interpretation after the amendment of 1852 (the form that came into practically all the codes) wotuld have permitted all the joinders made possible by Section 258 of the New York C. P. A. I920. For some strange reason the dropping of the word "equally" has never been noticed by the courts, and they have continued to construe the section as though it were present.

${ }^{30}$ Op. cit. supra note 23 .

sl This gave the section the character it now has in most of the codes.
} 
"2. In an action arising on contract, any other cause of action arising also on contract, and existing at the commencement of the action."

\section{It further provided:}

"The defendant may set forth by answer, as many defenses and counter-claims as he may have, whether they be such as have been heretofore denominated legal or equitable, or both. They must each be separately stated, and refer to the causes of action which they are intended to answer, in such manner that they may be intelligibly distinguished." 32

Here is another and new section dealing with joinder of causes of action, joinder within the answer, and joinder as between the answer and complaint. As in the amended original section it is provided, using old denominations, that legal and equitable causes of action may be joined. The separate statement is also a feature. The code of 1848 had provided for separately by stating as many "grounds" of defense as defendant might have, but there was no provision for separately stating causes of action. In the amendment of 1849 the separate statement feature was carried into the complaint, where it has since remained. The answer section of 1848 was comprehensive enough to include equitable defenses, but no express mention was made of them. With the express mention of legal and equitable defenses in the amendment of 1852 came a like mention of legal and equitable causes of action, and an expansion of the section on joinder of causes of action to make room for such joinders. As legal and equitable defenses were to be kept distinct for pleading purposes, through the separate statement, and defenses and counterclaims were grouped together for like treatment, we can hardly escape the conclusion that it was intended that legal and equitable causes of action, for pleading purposes, should not be merged into one comprehensive cause of action of either legal, equitable or mixed character, but that after their joinder they should be treated as fistinct units within the action.

To obtain the full significance of this requirement that legal and equitable causes of action, though joined in the same suit, should nevertheless be separately stated we must recall a feature of the equity practice. The chancery developed as a court because the writ system, administered through the common law courts, failed to keep pace with the growing needs of society. It became a court for the unusual cases, growing more common, not taken care of under the writ system. In its early development it was very strict in requiring parties to obtain what relief they could in the common law courts before applying for the extraordinary relief obtainable in the chancery. The chancery was a safety valve for the writ system, needed largely because the writ system fell into the hands of clerks, who, with typical clerical minds, refused to issue writs conferring jurisdiction on the courts except in those

$\approx$ N. Y. Laws, 1852, ch. 392 . 
cases where it had been done before. As this court developed the doctrine that a plaintiff must first seek the relief obtainable in the law courts before applying to the chancery for further relief not obtainable there became inconvenient to apply in many cases, and another competing doctrine developed to the effect that if adequate and complete relief could not be obtained at law equity would take jurisdiction in the first instance and, in the interest of preventing a multiplicity of actions, administer full and complete relief. These have remained competing doctrines in equity, the older doctrine never having fully given way to the newer, and a varied emphasis having been put on them by the courts. Liberal minded courts have practically discarded the old for the newer doctrine. Conservative courts have held back progress. As might be expected with a growing principle, it permeated some field more quickly than others, due to precedents in those fields being established by the liberal minded judges. However limited its application all jurisdictions have recognized the doctrine that equity having obtained jurisdiction will administer full relief.

We are now confronted with the important question, in administering the "full" relief what kind of relief was being administered? Was it legal relief if but for the operative facts which gave equity jurisdiction it would have been administered in the law courts? It was frequently so referred to that it might be distinguished from the grounds of equity jurisdiction in the first instance, but when we reflect that the only difference between "law" facts and "equity" facts is an historical one, founded solely upon the court in which we find them being dealt with, how can it be said that a "law" fact or a "legal" issue in the common law courts retains that characteristic in the equity courts? Accurately speaking, it did not. When this fact or issue came into the equity court, by reason of that fact, it became an equity fact or issue. Equity did not administer legal reliefs, it administered equitable reliefs only. They were equitable reliefs because equity. courts administered them. It was immaterial that they were identical with some reliefs administered on identical facts in the law courts. This becomes more apparent when we consider that the so-called legal issues and reliefs administered in equity were not administered through the common law medium of a jury. No common law characteristic came with them into equity. When they enter the equity household they become members of the equity family, and put on the equity garb. A complete and effective merger took place, wherein old characteristics were lost. Before suit brought one set of operative facts might be said to be legal, because they gave rise to legal relief only, but when to these were added other operative facts, giving rise to various reliefs in the equity courts, the complete set of facts calling for these reliefs was equitable. ${ }^{33}$

\footnotetext{
${ }^{2}$ It was a failure to appreciate the fact that there is no such thing as a legal issue or equitable issue apart from a legal or equitable cause of action that led
} 
After the merger there was one equitable cause of action, however many causes for action, cumulative or in the alternative, there may have been before. When parties brought their operative facts into an equity court they were governed by this merger principle, and lost all right of trial by jury of any of the issues. This was a thoroughly established principle when our constitutions were adopted preserving jury trials. It must not be forgotten, however, that a jury trial might be had, if desired, by taking those operative facts appropriate for administration in the law courts to such courts, the equitable relief being obtained later. The adoption of the liberal view above referred to with reference to the scope of equity jurisdiction to prevent multiplicity of actions did not lead courts before the code to extend a permissive jurisdiction into a compulsory jurisdiction, inasmuch as they never extended the inhibition against splitting a single cause of action into this field.

With the adoption of the codes the separate law and equity machinery disappears. One court administers both law and equity. What happens when a comprehensive group of operative facts, upon which there might have been separate applications for legal and equitable reliefs before the codes, is brought into the code court? If the code court is an equity court exclusively, if the equity part of the blend has completely swallowed up the legal part of the blend, our answer should be that this group of facts, including all issues, takes on an equitable character, should be pleaded as equity, and should be tried according to the equity method, that is, without a jury. If, however, the code court still has any' of the aspects of a common law court does this merger necessarily follow? May the plaintiff join a legal cause of action with an equitable cause of action so that, after the joinder, the legal cause of action preserves its identity? The study we have made of the amendment of 1852 leads to the deduction that he may. Not only may legal and equitable causes of action be joinéd, but, after joinder, they are to be separately stated.

The only possible object of the separate statement is to keep the causes of action separate for some purpose after suit. If the entire suit, after such a joinder, is to be tried as an equity suit, that is without a jury, it is difficult to see any purpose for the separation in the pleading. The amendment of the joinder of causes of action section in 1852 would have introduced no new element, and was superfluous. It could not have been intended to require, what was never required anywhere before, and what would be wholly impracticable, a separation into different counts of the operative facts affecting the various parties in an equity suit, on the ground that they were now to be treated as different causes of action in equity, nor is it believed that

Professor Clark to take exception to my criticism of DiMenna v. Cooper \& Evans Co. (I9I7) 220 N. Y. 39I, II5 N. E. 993 . See Clark, op. cit. supra note I2, at p. 837 . 
it could have been the intent to enlarge the code action so as to include two or more groups of operative facts for which the equity courts would have required several suits. The equity courts permitted all operative facts which could be conveniently dealt with together to be brought in a single suit, and such a contention would lead to the result that the code action could contain operative facts which could not be conveniently administered together,-an absurdity. It must be admitted the language of the section is broad enough to permit of such a result upon a literal interpretation, but it must be borne in mind that the language was taken from the answer section, which dealt in one statement with both defenses and counterclaims. Separate equitable defenses there could be, as well as legal and equitable defenses. The words "or both" in the section on joinder of causes of action could be given application to joinder of legal with legal causes of action, which would not be permissible without some such equivalent words. It is not necessary to extend them to include the joining of one equitable with another equitable cause of action, and courts generally have given them no such application.

Since the character of issues as legal or equitable is determined solely by the kind of court they were brought into before the codes, and since it was possible for a plaintiff to take into an equity court facts which might have been the basis of an action in a law court, taking advantage of the flexible character of the equity suit, and thereby making all the facts for operative purposes take on an equitable character, is it possible for a plaintiff, under the code, to accomplish the same result, thereby waiving his right of jury trial? The answer to this question must be in the affirmative, for there is nothing in the codes to indicate that the scope of an equity suit is curtailed. How, then, can we know that we do not have one equitable cause of action when the facts may take that character? The answer must be, by the form of the plaintiff's pleading. The character of the court can no longer determine it. But the plaintiff, by the express language of the codes, may join legal and equitable causes of action, separately stating them. If the plaintiff's pleading takes the form of a continuous narrative, with prayers for the kinds of relief sought, he has stated but a single cause of action, an equitable cause of action triable without a jury. If, however, he has grouped his operative facts in such fashion that each group, separately considered, calls for different reliefs, and one group calls for what before the codes would have been considered as legal relief only, he has joined legal and equitable causes of action, separately stated, and the legal cause of action, at his demand, should be triable by jury. The alternative is to penalize him for making the joinder by making such joinder a waiver, thereby encouraging him to adopt several actions instead of one. It can hardly be urged that the codes encourage multiplicity of actions. Such a construction militates against the purposes of the section permitting the joinder of legal and equitable causes of action. 
It should also be borne in mind that the section is permissive, not compulsory. The commissioners did not adopt the policy of compelling joinders wherever possible in the interest of reducing litigation. No such policy had existed either at law or in equity. Such a policy would introduce a lack of flexibility in actions, and impose an arbitrary rule which, in some cases, might work grave hardship. That there must be an irreducible minimum beyond which a plaintiff could not split up his operative facts into different actions the common law and equity courts both recognized, but that this irreducible minimum should consist of all the operative facts existent at one time which could be joined ${ }^{34}$ never occurred to any one until writers on the code began to declare that the nature and scope of a cause of action must be determined without reference to the number or kinds of relief asked, and must depend solely upon the number of primary rights and delicts disclosed by the operative facts. An amplification of this statement into the explanation that a single primary right and a single delict might be very complicated, which threw the doors wide open to make the cause of action as extensive as a particular interpreter might desire it to be, plus the fact that many equity suits were found to be very comprehensive, including operative facts which might have been the basis of a separate law action, led some courts to take the position that the cause of action must be of the scope that it might be, and that the bringing into the action of any operative facts by the plaintiff entitling him to any equitable relief necessarily waived a jury trial by him of all issues. Unless the joining of a legal cause of action with an equitable one merges the former into the latter there is absolutely no justification for this doctrine of waiver. ${ }^{35}$

\footnotetext{
${ }^{34}$ An interesting illustration of this is found in the cases of Bennett v. Allcott ( $1787, \mathrm{~K} . \mathrm{B}$. ) 2 Durnf. \& East $\mathrm{i66}$, and Bracegirdle v. Oxford. et al. (1813, K. B.) 2 Maule \& Sel. 77. In the first case defendant, a tax collector, went to plaintiff's 2 Maule \& Sel. 77. In the first case defendant, a tax collector, went ho privilege of entry, and debauched the plaintiff's daughter, who rendered service to plaintiff. In the second case it was alleged that defendant came on plaintiff's premises forcibly, under a false charge and assertion that plaintiff had stolen goods in her house, ransacked the house, and caused her credit and character to be injured among her neighbors present. Both actions were trespass quaere clausum, and in both the acts other than the forcible entry were so alleged as to characterize the trespass and aggravate it. Thus alleged it was held that plaintiff had but a single cause of action, but it was said that plaintiff had his option to proceed in this way, or to declare separately on the other acts as independent wrongs. There is no suggestion that if the latter course were adopted there would have been a splitting of a single cause of action.

In equity there were many illustrations of optional joinder or severance. A common case was that where a judgment debtor made a fraudulent conveyance of land or other assets. All judgment creditors could join in a suit to avoid the fraudulent conveyance, or any one might proceed alone without prejudice to the others. Brinkerhoff v. Brown, supra note 27; Van Zile, Equity Pleading (1904) sec. 493.
}

- ${ }^{35}$ The doctrine is most confused in New York, due to a failure to make the 
If it could be said that any single position with reference to the nature of a cause of action under the codes, or with reference to the effect of joining or failing to join legal and equitable causes of action, had become established, even in a single jurisdiction, it might seem presumptuous in me to take a position established by no line of decisions. My temerity in setting up an opinion utterly at variance with that of standard text writers, and at variance with what courts profess

distinctions noted. However, all but a very few of the cases may be harmonized by making it. In DiMenna v. Cooper \& Evans Co., supra note 33, in announcing that plaintiff waives jury trial by joining legal and equitable causes of action, the first case cited is Davison v. Associates of the Jersey Co. (1877) 7I N. Y. 333, 340. The next case cited is Cogswell v. N. Y., N.H. \& H.R.R. Co. (I887) I05 N. Y. 3I9, II N. E. 518. Then, among others, Wheelock v. Lee (I878) 74 N. Y. 495, 500 , is cited. That these cited cases make the distinction I have contended for is not noted. In the Davison case the complaint was framed as an equity bill, and, in holding that plaintiff waived his trial by jury the court (p. 340) makes its decision to turn on this form of the complaint. The Cogswell case relies on the Davison case, and there, too. the complaint was framed as an equity bill. The court says that where the plaintiff brings an action for both legal and equitable relief "in respect of the same cause of action" he elects to have the case tried by the court (italics are mine). The language, carefully considered, raises the question whether the two reliefs may be asked with reference to different causes of action. The question is answered in the affirmative in the case of Wheelock $v$. Lee, where the plaintiff used five counts to set out the operative facts, the first four of which set forth legal causes of action only, and the fifth set forth an equitable cause of action. Though it was defendant who asked for the jury trial, the court makes the defendant's right turn on the form of the complaint in separate counts, and not on the fact that defendant stands in a more favorable position than plaintiff on a single narrative praying for both reliefs: If the action is equitable for one it is surely equitable for both, though the plaintiff may have the option to determine its character just as he did before the codes. Losing sight of the distinctions made in the cases cited, the court in the DiMenno case seems to generalize, holding that in all cases of joinder plaintiff waives his right, but that in no case of joinder can he take away the defendant's right, producing the peculiar situation of having the case legal for plaintiff and equitable for defendant. In that case it was held defendant did not waive his right though he brought a counterclaim of a legal character into an equity suit. In other words, if plaintiff does the joining he waives, but if defendant does the joining there is no waiver. Quite naturally the court could not long be held together on such a doctrine. InCity of Syracuse v. Hogan (rg23) 234 N. Y. 457, I 38 N. E. 406 , it swung to another extreme, holding that though the complaint in single narrative form contained appropriate grounds for equitable relief it in effect set out but a single legal cause of action in ejectment, because the injunctive relief sought depended upon a settling of title and right to possession, and that, therefore, defendant was entitled to a jury trial. It intimated, and its argument went to prove, that plaintiff would have the same right. It failed to take cognizance of the fact that the liberal group of equity courts, of which New York was one before the code, would determine title and right to possession as an incident to equitable questions involved. Cardozo, J., who wrote the opinion in the DiMenna case, dissented, and was joined in the dissent by two other members of the court. When the court comes back to the distinctions pointed out in the Davison and Wheelock cases the confusion and disagreements will disappear. 
to follow and do not find it possible to follow consistently, ${ }^{36}$ grows out of the hope that a re-examination of the entire question along basic lines may bring us out of the chaos in which we now are.

Let me now take direct issue with and point out the fallacy in the statement that the character and scope of a single cause of action should be determined without reference to the kind or number of reliefs sought, and that it should be determined solely from the number of primary rights and delicts involved, or by the trial judge pragmatically with a view to his notion of administrative convenience. The indefinite scope of single rights and single wrongs has.already been suggested. I boldly take the position they will be found only in a study of remedies, because it was in connection with them that our concepts as to the scope of rights and delicts were developed. Rights and wrongs may be dealt with in the abstract without reference to remedies. We may admit that there is no occasion for remedies until there has been a prior recognition of rights and wrongs. We may admit there are primary rights, meaning thereby, rights which exist independently of and prior to either wrongs or the secondary remedial rights. But when we begin to draw dividing lines between rights growing out of associated facts it is because we have some remedial purpose in mind. If there is a dividing line between substantive law and procedure for purposes other than study, rights and wrongs in the abstract belong in the field of substantive law, but single rights and single wrongs relate themselves to procedure. This can be made clear by only a brief glance at some early pages in our law.

In the days when the Norman kings were drawing the important litigation from the local to the king's courts, the king's writ, issued through the medium of his chancellor, was the authority of these courts to proceed. When, at a very early time, it became the custom to set forth in these writs the nature of the complaint made, directing the party complained of to do justice in respect thereto or show cause in one of the king's specified courts at a particular time why he had not, the court's jurisdiction of subject matter in a particular case was limited to the subject matter contained in each writ. ${ }^{37}$ Whether there was or was not a right or a wrong was determined with reference to that subject matter only. No single right or wrong was conceived of as having a broader scope than the subject matter of the writ. If Doe obtained a writ of trespass against Roe, wherein complaint was made that Roe had come forcibly on Doe's land, the right in which the court was interested centered around Doe's possession of the property, Roe's duty to stay off of it, and Doe's right to have him stay off. This right and duty were primary, as the term "primary" is used by Mr. Pomeroy, because they existed before any delict by defendant, but

${ }^{36}$ See comment on DiMenna and Hogan cases in preceding note.

${ }^{\text {s7 }} 3$ Blackstone, Commentaries, p. 273. 
the only reason why this primary right did not include the incidents of ownership and kind of estate, relations with tenants, claims of title made by others, use of the land by Doe and others, was that the complaint did not involve them, the writ did not include them, and the court had no jurisdiction to inquire into them. For the purposes of that particular investigation the plaintiff had but one right, and that one right was the right of undisturbed possession of land. So if it were claimed that a tenant had committed waste an appropriate writ permitted the landlord to have a judicial inquiry made into that fact. For the purposes of this proceeding the only right involved was the right of the landlord not to have his tenant commit waste.. Conditions were primitive, and wholesale complaints were unusual. A writ was issued to grant relief for a specific grievance. If the facts stated to the chancellor were of a character which he recognized as giving the complaining party a right to relief, according to the concepts of the times, the writ issued, otherwise not. When the copies of former writs issued, kept as a register of writs, ceased to be a form book and, in the hands of clerks, in true clerical fashion, became a book of rights, and when rights were classified according to the writs, it was inevitable that in the thought of the times a single right should be regarded as confined to the matters dealt with in a single writ. What might, under a different system, have been the single comprehensive right contended for by Mr. Pomeroy and others was split up into different rights through the writ system, and through it a single right was related to a single distinctive kind of remedy. The remedy may be considered as not being a part of the primary right in the sense that the right antedated the remedy, but when we come to speak of single rights we find the remedy shaping the scope of the right although it be not a part of it.

Those who contend for the comprehensive single right which is unaffected by remedies are doubtless trying to take us back of the crystallized writ system on the theory that the abolition of the distinctions between the common law forms of action by the codes necessitates that result. They argue that because the code makes provision for a demand in the complaint of the relief that the plaintiff "supposes himself to be entitled to," thereby making it possible for him to demand one relief and get another under some circumstances, the demand is no part of the cause of action and, hence, must be utterly disregarded in determining its character and scope. The reasoning is plausible to one who jumps to hasty conclusions, but close study by one having a knowledge of the background shows it to be disjointed and to contain a non sequitur. If law actions can and have survived the codes despite the fact that the distinctions which kept them from being administered in one suit have disappeared, it is but natural to conclude that the concepts which developed in connection with them also survived. Even if the reader is unable to agree with me that the law actions have survived 
I think he will be willing to admit that a change in the law of remedies after centuries of use of an older system does not necessarily affect concepts in the law of rights. With crystallization of writs came likewise crystallization of thought with respect to singleness of rights, and when a people has once obtained a concept as to the nature and scope of a single right a change in remedies will not affect that concept unless the nature of the new remedies makes it imperative. It is much easier to change machinery than it is to change methods of thinking. Much confusion has beèn introduced by Mr. Pomeroy, and those of his school of thought, by attempting to readjust modes of thinking. where readjustment was not necessary, and by giving no tangible concept capable of being grasped and retained in substitution. Mr. Pomeroy's book is full of illustrations of retention by him of the common law idea of singleness of rights, and it is only when he indulges in abstractions that he tries to carry us away from this idea to the new, which is an abstraction. Mr. Pomeroy does not seem himself to realize from whence his notion as to the scope of a right comes, and with no sense of direction from which it has come it is not strange that he has been unable to give it direction to proceed.

In order to emphasize the important fact that a relief sought may characterize and shape the scope of a right without becoming a part of the right, and that likewise a relief sought may characterize and determine the scope of a cause of action without becoming a part of the cause of action, let me suggest the homely illustration of a married man. Only in an ecclesiastical sense is his wife a part of him, yet most surely she characterizes him as a married man. In determining whether he is a married man, or whether he has a larger freedom of action, his wife cannot be ignored. Many married men have tried it with disastrous results. As we live in a concrete world we find married rights: For the purpose of this article we need not inquire whether bachelors and old maids can be found here and there. For the most part rights and remedies are married, or at least affianced. In letting our gaze linger admiringly on a right we must not forget that a jealous remedy may be standing near by. Sooner or later we will come to earth with the realization that the individual right has very definite limitations. In the chancery alone do we find one right having a harem of remedies. The writ system did not prevail there, and, consequently, exercised no dividing influence. But the number and kinds of remedies which might be brought together was limited by an administrative rule of convenience. ${ }^{38}$ They might be few or numerous. There was a maximum limit beyond which joinders might not go, and there was a minimum limit below which plaintiff could not split

\footnotetext{
${ }^{38}$ Story, op. cit. supra note 27, secs. 76c, 27. , note a, 279, 280; Sheldon $v$. Packet Co. (I881, C. C. W. D. Wis.) 8 Fed. 769 ; Brinkerhoff v. Browen, supra note 27 .
} 
the suit. 39 Between these limits the size of the group of operative facts brought within the suit might vary. ${ }^{40}$ If one remedy of an equitable nature only were sought, and the operative facts entitled the plaintiff to that one remedy only, the courts must have found a right within this limit. If more facts were brought in, entitling one or more plaintiffs to several reliefs, still there might be but one right, expanded into a more comprehensive character, in which the several parties would be interested. The scope of one equitable right can not be determined without a study of the manner in which the equity courts administered equitable remedies, for it was in connection with this administration that the concept developed.

In our brief glance at the common law system we saw that one right could not bridge two writs. It does not follow, however, that all the operative facts within one writ necessarily pointed to one right. While the writ was a dividing factor, it was not the only one. It was not at all uncommon for one writ to issue for trespasses to two or more parcels of land, for breaches of distinct contracts, and for the recovery of chattels taken at different times, yet there was no thought that there was a single right to two parcels of land, in two contracts, nor in two chattels when taken at different times. The writ might protect one right or it might protect several rights of the same nature, each right springing from a particular group of operative facts. The principles of law brought into play by each group of facts within the writ, though generally similar, would be related to different situations, and might vary in minor details. If juries were to render general verdicts it was essential that they be told the particular principles applicable to each group, so that they might know the nature and extent of the distinct rights. Even if they rendered special verdicts, a more common practice formerly than now, it was necessary for the trial judge to tell them what things they might consider in deciding the ultimate issuable facts pertinent. Whether the general or special verdict would be sought on the trial could not be told at the time pleadings were being settled, and it was necessary to adopt general rules as to the form of pleadings which would be suitable whatever mode of trial was adopted. The count feature of common law pleadings was splendidly adapted to this purpose. Hence we find the common law count setting out the operative facts giving rise to a single right and showing a single delict. The writs divided rights and delicts of different kinds, involving totally dissimilar principles. The counts divided rights of the same kind involving similar principles. The system of division by writs may have become too arbitrary to meet the needs of modern litigation, but in preserving the separate statement in

${ }^{2}$ Story, op. cit. supra note 27 , sec. 287 .

${ }^{\infty}$ For excellent statements of the equity rules as to joining parties, showing there was a large optional class, see Payne $v$. Hook (I869, U. S.) 7 Wall. 425; Hicklin v. Marco (1893, C. C. A. 9th) 56 Fed. 549. 
the code complaint as well as the separate statement of defenses in the answer the commissioners indicated that they did not believe that the count system had outlived its usefulness in jury trials, and we see why it was inserted in the section on joinder of causes of action by the amendment of I849. As one count would embrace all of the equitable features of a single litigation, it served also to separate the legal from the equitable causes of action when legal and equitable causes of action were brought together by the amendment of $185^{2 .}{ }^{4 x}$

I think we are now prepared to give a fairly accurate definition of the cause of action. It is that group of operative facts which, standing alone, would show a single right in the plaintiff and a single delict to that right giving cause for the state, through its courts, to afford relief to the party or parties whose right was invaded. ${ }^{22}$ The singleness of the right and delict is determined by a study of the old remedies in connection with which the concepts as to singleness of rights and delicts developed. The number and kinds of groups of fact of this character which might be brought together in a single suit was formerly determined by rules which developed out of the writ system, but is now determined by the special provisions of the subdivisions of the sections on joinder of causes of action in the codes. Because the jury system is preserved for the trial of law actions, and because the scope of the common law cause of action developed in connection with such mode of trials demonstrated by experience that it was suited to such trials, the legal cause of action under the codes is the same as before the codes. Likewise since the scope of the cause of action in the equity courts proved through experience that it was suitable to the trial of equity suits, it was retained unchanged. In the code court legal and equitable causes of action could be brought together in the same action, each having its appropriate mode of trial. This could be worked out in individual cases either by the trial judge passing upon the equity features of the case, submitting the legal phases to the jury under appropriate instructions, under one hearing of all the facts, or, if it was thought undesirable to have the jury hear the equity phases of the case, by the trial of either apart from and in advance of the other through the sections providing for the trial of some of the issues in advance of others. The desired flexibility of the action is obtained through the permission to join and try separately or try together numerous causes of action, which was impossible under the old systems. This flexibility is obtained without mixing up facts calling for the application of unrelated principles of law, requiring a busy trial judge to unravel them, in a limited time, without depriving any of the parties of a right of trial guaranteed by constitution, and without introducing new

*heelock v. Lee, supra note 35. •

the distinction between this and the definitions given by Pomeroy, Bliss and Phillips lies in the directions given for ascertaining the scope of a single right and a single delict, and that it is definitely tied up to remedies. 
and inconvenient applications of the rule forbidding the splitting of single causes of action..$^{43}$ If this requires formality in pleadings the justification for it lies in the benefits derived, and the confusion consequent upon a system which makes pleading easy and trials difficult.

There may be a reasonable difference of opinion as to whether the count system should have any application to the presenting in the complaint of different theories of a single recovery, as was done at common law. Are the groups of facts sustaining these different theories different causes of action, or merely different ways of setting forth the same cause of action? It must be admitted at the outset that courts and writers of eminence have frequently referred to the situation as one where but one cause of action is set out, and no less an authority than Stephen so refers to it in connection with common law pleading, where the practice began. He says:

"The use of several counts, when applied to distinct causes of action, is quite consistent with the rule against duplicity; for the object of that rule, as formerly explained, is to prevent several issues in respect of the same demand only; there being no objection to several issues, where the demands are several. But it happens more frequently than otherwise, that, when various counts are introduced, they do not really relate to distinct claims, but are adopted merely as so many different forms of propounding the same canse of action; and are, therefore, a mere evasion of the rule against duplicity. This is a relaxation of very ancient date and has long since passed, by continual sufferance, into allowable and regular practice." .

After giving some illustrations of the practice, he continues: ${ }^{45}$

"It is to be observed, that whether the subjects of the several counts be really distinct, or identical, they must always purport to be founded on distinct causes of action, and not to refer to the same matter."

It is apparent from this discussion that Stephen made a distinction between what he considered really distinct causes of action, and only what purported to be such, and were set out as such in the declaration to avoid the rule against duplicity. Other writers, and courts, have made the same distinction. Let us look at it. We are supposing there is only one true group of operative facts, and that this is the group of facts which will ultimately determine the outcome of the suit. Stephen refers to the different modes of setting them forth, either for the purpose of making the pleading sufficient in law, or for the purpose of avoiding a variance on the trial. The pleader may be fearful that the first attempt does not comply with all the rules of law, and wishes to fortify himself by another form of statement. He may be fearful that the facts as first pleaded will not be sustained by the proof, and

${ }^{4}$ An illustration of this is discussed infra.

" Stephen, Pleading (Am. ed. I824) 284. As to the origin of the rule forbidding duplicity, and of the count in connection therewith, see notes 57 and 59 to Mr. Stephen's text in this edition.

${ }^{45}$ Ibid. 288. 
he wishes a form of statement the proof will sustain. The reference is to form of statement of the same thing, but with all due respect to the learned author the different forms do not state the same but different things. If they stated the same thing there would be no occasion for multiple statements. The multiple counts were used to introduce new or alternative sets of facts. The various sets of facts pleaded were not identical, and only one set of facts was true. The difficulty was that the pleader might not be certain as to the importance of one or more facts, or he might not know which of several possible facts the jury or judge might find were true. Different hypotheses were permitted to be pleaded, but only the hypothesis proved gave the plaintiff right to relief. The different hypotheses might seek the same relief, relief of the same character, varying in extent, or reliefs of different kinds. The true hypothesis described the plaintiff's cause of action. The false hypotheses did not describe it, but causes of action which did not exist. The different counts, then, were not different forms of stating the same cause of action, but statements of different causes of action, some of which were fictitious.

The distinction just made between different forms of stating the same cause of action, and statements of different causes of action, all but one of which are fictitious, is important in determining what we mean by inconsistent causes of action, which many of the codes forbid us to join. ${ }^{48}$ Because of a failure to make this distinction, or to see its possibility, courts have found it impossible to follow any consistent path in determining when there is and when there is not inconsistency. Every count, under the circumstances being discussed, is, in a sense, inconsistent with every other count, it being impossible for each hypothesis to be true. In applying the prohibitive clause do we refer to inconsistent hypotheses? Mr. Stephen's answer undoubtedly would be that we do not, for we have, under his analysis, only one cause of action. How, then, is it possible to have inconsistent causes of action? Can one truth be inconsistent with another truth? We must find the solution in another direction. If inclined to jump to hasty conclusions we will say that the clause must have meant purported causes of action, and that the count system cannot be used under these codes for presenting different theories for one recovery. As this is certainly a possible meaning let us see what it involves.

There is no practical way in which a plaintiff, in advance of the trial, can become certain what group of operative facts is true in all its parts. There may be honest differences of opinion among his own witnesses, or between his witnesses and those of his opponent. The differences may be material or immaterial. The material differences may affect the relief obtainable, though either view will give some

${ }^{15} \mathrm{New}$ York C. P. A. I920, sec. 258. The provision was not inserted in the New York code until the revision in 1877 , though the New York courts had been announcing it before, giving it various applications. 
relief. A witness of an opponent may testify to a state of facts somewhat different from that relied on by plaintiff, but nevertheless favorable to him. Skillful cross-examiners frequently make their cases out of the witnesses of opponent through a careful study of the varying theories upon which a recovery may be had. At the close of all the evidence it may be apparent to everybody what the true state of facts is, in which case it is unnecessary for a jury to function; but, on the other hand, the jury or judge may have to settle conflicts, and the true cause of action is not known until the final arbiter speaks. If justice is to be done plaintiff some provision must be made for the variable fact element. If he alleges the facts as he believes they will turn out to be and his expectations are disappointed, but not to the extent of destroying his right to all relief, what shall be done? We cannot answer this question satisfactorily until we have agreed upon the purposes of a pleading. ${ }^{47}$ Certainly one purpose is to give notice to an opponent of the facts to be brought against him that he may have an opportunity to meet them. If the variance is immaterial, so slight as not to take the defendant by surprise and prejudice the presentation - of his defense, the trial may proceed, the pleading being amended or not depending upon whether the judgment upon the unamended pleading would entail different results from a judgment on it as amended. But if the variance is material, substantially affecting defendant, the trial certainly cannot proceed on the single direct narrative in the pleading. A postponement must result, with the necessity of going over much of the evidence again. What will happen if some of the evidence tends to support the theory upon which the pleading is apparently drafted, but other evidence comes out tending to support a theory which the facts pleaded would not support? Should the jury be permitted to consider this surprise evidence? If the surprise be to plaintiff only the answer should be in the affirmative, but if it.be a surprise to defendant also the answer must be in the negative, and again there must be a postponement of the trial, involving repetitions. Is there no way in which these postponements may be avoided in fairness to both parties?

It has been said that the solution lies in alternative pleading, not the indirect method of the common law by counts, ${ }^{48}$ but by the natural and direct method of alleging that the facts were so and so or so and so. It is claimed that this is a much more simple method of pleading than the use of the count system. It does or does not avoid the prohibition

\footnotetext{
${ }^{47}$ The Code Commissioners thus explained their function: "Their object is threefold; to present the facts on which the court is to pronounce the law; to present them in such a manner, as that the precise points in dispute shall be perceived, to which the proofs may be directed; and to preserve the record of the rights determined." First Report, p. I37.

${ }^{4}$ Hankin, Alternative and Hypothetical Pleading (I924) 33 YALE LAW Journat, 365 ; Clark, op. cit. supra note I2, at pp. 8I7, 826.
} 
against joining inconsistent causes of action depending upon whether the true facts go to make up the cause of action or the hypothetical facts. This method of pleading does not avoid pleading hypotheses, but merely pleads them in a different way. If pleading hypotheses is objectionable this form of pleading cannot stand. It falls in exactly the same category as the count system. If the cause of action is the true hypothesis only, neither it nor the count system falls within the prohibition, and we must seek farther for the meaning of inconsistent causes of action. While the alternative pleading has the claimed merit of simplicity of form, and, perhaps, gives the defendant as much notice as the count system of pleading, complications arise at later stages. How shall defendant plead to it? The answer is that he may deny all alternatives, admit and avoid all, or deny some and admit and avoid others. In his pleadings by way of avoidance defendant may wish to introduce new, but uncertain, facts. If alternative pleading is good for plaintiff it is likewise good for defendant. If the "ors" in the complaint are many, and there is no reason why they may not be as numerous as the counts used under the other system, each "or" in the complaint must be accompanied by sufficient succeeding "ors" to show a . ground for relief on each hypothesis and branch hypothesiş. The defendant must untangle the various hypotheses created by the various "ors," and meet them with his direct allegations or his "ors." The issues thus presented must be unscrambled by the trial judge to rule intelligently on the materiality of evidence under the issues, and to charge the jury as to the issues. Upon pleadings thus framed must be determined the right to the provisional remedies of attachment and arrest. How is the verdict to be related to the proper alternative so that the judgment will preserve the record of the rights determined? Even if we get by the difficulty of the plaintiff separately stating his causes of action, by saying that alternatives are not different causes of action, has defendant complied with the provision that he separately . state his defenses? Are the different alternatives also the same defenses? Even if it be possible to solve all the difficulties connected with an alternative method of pleading, is it worth while, in view of the certain difficulty following at later stages to so "simplify" the complaint? Bearing in mind that a pleading serves several purposes other than the giving of notice to an opponent, aids in sifting out groundless actions in advance of trial, aids in an orderly presentation of issues to a jury, and plays a part in recording what has been done, is it in the interest of simplification of practice to so simplify a pleading as to destroy much of its effectiveness?

But we have not solved the problem as to what are inconsistent causes of action. If inconsistent hypotheses, whether presented by the count system or by the direct method of pleading alternatively, are not inconsistent causes of action; if only the true hypothesis is the cause of action, and there can be no inconsistency to what is true, is it possible 
to find a meaning, or has an impossibility been attempted? The courts have not solved the problem. It has not been solved because of the aversion to looking at remedies when seeking the character of the cause of action. If my analysis set out heretofore is correct, showing that the relief sought characterizes the cause of action, and that the nature and scope of the cause of action cannot be determined without a consideration of the relief sought, the solution is easy to see and easy to apply. Where, upon identical operative facts, a plaintiff seeks alternative reliefs, the plaintiff has joined inconsistent causes of action. Where, upon variable operative facts, he seeks alternative reliefs he has not joined inconsistent causes of action. Where the relief only is variable, and the plaintiff establishes one set of facts or none, there is no reason why plaintiff should not choose the remedy he wishes in advance of suit. There is no reason for vacillation on his part. If, however, there is uncertainty as to some of the facts, and one relief or the other is given dependent upon which of the alternative facts are true, until the facts are settled definitely there is a real reason for postponing a choice of remedies, and an election should not be forced until jury or judge settles the facts. As the relief prayed for characterizes the causes of action, identical facts calling for different reliefs are inconsistent causes of action, but variable facts calling for the same or different reliefs are not. The variation in the facts prevents the inconsistency. Only one set of facts may be true upon the final determination, but the state, through its courts, acts, and has cause for acting, in the first instance, as though the hypotheses are entirely different and unrelated facts, and hence true and consistent. If the cause of action is a group of operative facts which will cause the state to act on behalf of a party, to understand it we must look to see the mode in which the state acts, and ascertain why it acts that way. It is not sufficient to know abstractly that the state will act some way some time.

The amendment of 1852 brought a new subdivision into the section on joinder of causes of action which has had its influence in obscuring the nature of the cause of action. It provided that plaintiff might join "causes of action arising out of the same transaction, or transactions connected with the same subject of action." The term "transaction" and "subject of action" have been most puzzling to the courts, as well as to text writers. ${ }^{49}$ The difficulties with the term "transaction" can be illustrated by a few cases, dealing with the same set of facts,-an assault accompanied with defamatory words in the presence of others.

\footnotetext{
- Pomeroy, op. cit. supra note 4, secs. 357-368, with many cases cited; McArthur v. Moffett (1910) I43 Wis. 564,128 N. W. 445 , citing cases; Wiles v. Suydam (1876) 64 N. Y. I73. The English courts likewise found difficulty with the term. Hannay v. Smurthwaite [I893] 2 Q. B. 4I2, 420, 425; overruled in House of Lords, taking a different view of the meaning of "transaction," in [1894] I9 A. C. 494. The term has now been carried into the section on joinder of parties plaintiff in the New York C. P. A. 1920, sec. 209.
} 
In Brewer v. Temple, ${ }^{50}$ a demurrer to a complaint setting forth an assault and slander in a single count on the ground there was a misjoinder of causes of action was overruled, the court saying:

"The complaint in fact contains but a single cause of action. The complaint purports to give the history of one occurrence, and no more. This history embraces what was done and what was said upon the occasion. $\quad \ldots$ What is alleged to have been done, would, if established upon the trial, sustain an action for personal injury. What is alleged to have been said, would, if established upon the trial, sustain an action for injury to the reputation. The whole together, constituting as it does but a single transaction, makes but a single cause of action."

The Kansas Supreme Court, ${ }^{51}$ on a similar complaint and demurrer, cited Brezver v. Temple as an authority for the proposition there was but a single cause of action, but said that as that question had not been argued it would assume there were two. It reviewed the common law situation, pointing out that a joinder there would not have been permitted, that the code had adopted a more philosophical system patterned after the rules in equity designed to avoid a multiplicity of actions, and that the two causes of action could be joined because they arose out of the same transaction.

Twelve years after the decision in Brewer v. Temple the Supreme Court of New York ${ }^{52}$ passed on the same question again. In condemning the decision in that case it said:

"The complaint here, as in that case, states facts constituting a clear cause of action for an assault and battery, and also a clear cause of action for a verbal slander, both in single count.... both are intermingled and woven together in a single fabric of manual and vocal tort. Causes of action for words and blows are thrown into 'hotchpot,' and counted upon in that condition."....

"It by no means follows that because the two causes of action originated, or happened, at the same time, each cause arose out of the same transaction. It is certainly neither physically nor morally impossible that there should be two transactions occurring simultaneously, each differing from the other, in essential attitudes and qualities."

Then follows a very earnest argument, pointing out the essential differences between the subject matter of the assault and slander; that they were in different classes at common law and under the code, provable by different evidence, and met by different defenses, with nothing in common. Later the Court of Appeals approved the holding in this case, ${ }^{53}$ citing Mr. Pomeroy to the same effect. It had already decided that facts showing a breach of a covenant of quiet enjoyment by a trespass on the lands covered by the covenant, pleaded so that

${ }^{50}$ (1857, N. Y.) 15 How. Prac. 286.

"Harris v. Avery (1869) 5 Kan. I46.

${ }^{\circ}$ Anderson v. Hill (I869, N. Y.) 53 Barb. 238.

* DeWolf v. Abraham (1896) r5I N. Y. 186, 45 N. E. 455. 
one statement relied on the trespass and the other on the breach of the covenant, stated two causes of action arising out of different transactions. ${ }^{54}$

Revolting against these decisions, the legislatures of Connecticut and New Jersey, without giving a complete affirmative definition of the "transaction," provided as follows : ${ }^{55}$

"Transactions connected with the same subject of action may include any transactions which grow out of the subject matter in regard to which the controversy has arisen; as, for instance, ... the breach of a covenant of quiet enjoyment by the entry of the lessor, and a trespass to goods committed in the course of the entry."

The New Jersey act adds:

"or several torts committed simultaneously as a battery accompanied by slander."

In Wiles v. Suydam ${ }^{56}$ the New York Court of Appeals held that a complaint by a creditor of a corporation against a stockholder and trustee, seeking to establish against him a statutory liability for the debts of the corporation, (I) as stockholder because no certificate had been made and recorded that the capital was paid in, and (2) as trustee because no annual report of the corporation had been filed with the Secretary of State, not only stated two distinct causes of action, but that they did not arise either out of the same transaction, or out of transactions connected with the same subject of action. The liability as stockholder was limited to the amount of stock held, while the liability as trustee had no such limitation. In the later case of Payne v. N.Y., S. \& $W . R . R$. Co., ${ }^{57}$ the same court held that a complaint by an injured brakeman against a railroad company for failure to furnish safe appliances based upon (I) the common law duties of a master to a servant, (2) the statutory duties imposed by the New Jersey Employers' Liability Act, and (3) the statutory duties imposed by the Federal Employers' Liability Act, stated but a single cause of action. The liability acts took away the defenses of contributory negligence and assumed risk if the appliances required were not furnished, and contained minor differences between themselves. In case of the death of the employee, and action by his administrator, the measure of recoveries differed under the Federal and state acts. ${ }^{58}$

\footnotetext{
"Keep v. Kaufman (I874) 56 N. Y. 332.

${ }^{55}$ Conn. Prac. I908, p. 245, sec. 150; Sheen, N. J. Prac. Act (IgI6) p. 222, sec. 307 .

(I876) 64 N. Y. I73.

${ }^{6}$ (I9II) 201 N. Y. 436, 95 N. E. I9.

${ }^{*}$ Under the Federal act the cause of action of the decedent survives to the administrator, and with this is combined the usual recovery by the administrator of loss to the next of kin by reason of the death. St. L. I. M. \& S. Ry. v. Craft (I9I4) 237 U. S. 648, 35 Sup. Ct. 704; Lennon v. Erie R. R. (I9I8) 92 N. J. L. 209, 104 Atl. 444
} 
It will be seen from the cases cited that there have been two views as to the nature of the "transaction." According to one view it is a series of acts constituting a single event, looking at an event as the layman looks at it. According to the other view it is a series of acts constituting a single event, looking at an event through the lawyer's eyes. In the one case it has no legal characteristics or limitations. In the other it is definitely tied up to legal principles. When a group of facts is severed because no one set of legal principles will apply to all, and when we see in a transaction only such limited group as can have one set of legal principles applied to it, we have identified ourselves as lawyers, interested not in story telling as such, but in the kind of story telling which has a definite relation to judicial machinery. The courts have taken both views, wandering from one to the other. The Connecticut and New Jersey legislatures have definitely committed themselves to the layman's interpretation of the transaction. They have done more, injecting the layman's method of thinking into the cause of action, and making it more difficult to distinguish the cause of action from the transaction. Both have sections reading: $:^{59}$

"When separate and distinct causes of action (as distinguished from separate and distinct claims for relief, founded upon the same cause of action or transaction) are joined, the statement of the second shall be prefaced by the words Second Count, and so on, for the others."

The parenthetical characterization of the cause of action as something apart from claims for relief is a statutory creation of a cause of action different from that developed in the courts prior to the code. It is an adoption of the Pomeroy-Bliss-Phillips concept, to the extent that one cause of action can give rise to different reliefs. It carries the suggestion also that one transaction giving rise to separate and distinct claims for relief, as well as one cause of action doing the same, is a cause of action for the purposes of separate statement, and there'by confuses the layman's and the lawyer's concepts of the cause of action. The Connecticut and New Jersey cause of action, being torn loose from limitations imposed by association with legal principles, is difficult to distinguish from the layman's transaction. ${ }^{60}$ On the other hand, the lawyer's concept of the transaction, above described, is difficult to distinguish from the lawyer's concept of the cause of action limited in scope by legal principles related to specific remedies.

The solution of the riddle seems to lie in the acceptance of the lawyer's concept of the cause of action and the layman's concept of the transaction. The term "transaction" never had legal associations before the codes, and has never had since, except in the sections under discussion. On the other hand, the term "cause of action" was a definite legal concept, associated with procedure, long before the codes. Few laymen would have any hesitation in saying that an assault accom-

${ }^{3}$ Conn. Prac. I908, p. 240, sec. I32; Sheen, op. cit. supra note 52, p. 232, sec. 330.

${ }^{\infty}$ Craft Refrigerating Co. v. Quimipiac Co. (1893) 63 Conn. 55I, 29 Atl. 76. 
penied by verbal defamation constitutes a single transaction, since they are not thinking in terms of legal principles fixing liabilities and defenses, and modes of grouping sets of fact for trial purposes. The lawyer, accustomed to this mode of thought, seeing the unrelated legal principles, calling for different issues, not only sees two transactions, but sees no point of contact between them for trial purposes. The commissioners, being lawyers familiar with legal terminology, but also being impressed with the necessity of a more liberal application of the rules with reference to joinder of causes of action than that adopted in the common law courts, by the amendment of 1852 brought into the section on joinder of causes of action the principle of administrative convenience found in the equity rules on joinder of parties and subject matter. They had already used the term "subject of the action" in the section on joinder of parties to describe the indefinite and elastic scope of the operative facts in which the parties must have an interest to join. ${ }^{.1}$. A prospective look is taken at a suit properly constituted, and the subject matter of that suit is taken to be the "subject of action" - in which the parties must have an interest. Unless the properly constituted suit can be seen the "subject of action" means nothing, and thought travels in a circle. If, however, we see the principle of administrative convenience fixing the scope of the properly constituted suit "subject of action" becomes more tangible, something in which we can fix interests. It is likewise a concept helpful in fixing the scope of an action into which legal causes of action are being brought. It is the totality of operative facts which, determined by the principle of administrative convenience, can be dealt with in one suit. Within this larger mass the smaller units, the causes of action, may be found. The size of the mass may be determined in part by the method in which smaller units are stated, and the mode of trial will undoubtedly affect it. Its scope is as flexible as the needs of the particular suit and policy as to joining and severing the smaller units may dictate. There is ample authority to support this view of the "subject of action" as applied to joinder of parties, ${ }^{62}$ and there is every reason to believe that it should be so interpreted in the section on joinder of causes of action and the counterclaim section. ${ }^{63}$ The problems in all the sections are problems in joining subject matter, and there is no reason why like principles should not apply to all.

If the "cause of action" and the "subject of action" are legalistic

a Supra note 27.

"Shepard v. Manhattan R. R. (I889) II7 N. Y. 442, 23 N. E. 30; Barnes v. Midland R. R. Term. (I9I6) 218 N. Y. 9I, II2 N. E. I053; Young v. Franklin Co. Commirs. (1865) 25 Ind. 295.

${ }^{6}$ Cf. Crouch, J., in Sherlock v. Manwaren (1924, 4th Dept.) 208 App. Div. 538, 203 N. Y. Supp. 709, a decision of which I heartily approve despite the criticism leveled against it by Professor Clark, op. cit. supra note 12, at p. 834 . Seo also Pomeroy, op. cit. supra note 4, sec. $384 ; M c$ Arthur v. Moffett, supra
note 49 . 
concepts related to remedies, and "transaction" is a layman's term, how did it come that the layman's term was used in connection with the terms of art, and was anything added by' it? Was it necessary to introduce the idea of a third unit, intermediary between the cause of action and the subject of action? Certain it is that in the codes other than the Connecticut and New Jersey codes it was not intended that the "transaction" should be marked by any separations in the pleading. It was the "cause of action," not the "transaction," that was to be separately stated. What then was meant by "transaction" in codes generally? I am not sure I can give a satisfactory answer to these questions, but I will venture a guess. In searching for a satisfactory terminology to express the more elastic rule of joinder desired some one may have suggested that it would be expressed if it were provided that all causes of action could be joined which arose out of a single transaction, using "transaction" in the layman's sense. If a wide enough scope were given to the transaction this might be possible, but it may have been suggested that there would be conflicting opinions as to the scope of a transaction, and that, as a result, many desired joinders might be defeated. Another may have called attention to the equity rule, and the way it was expressed in such cases as Brinkerhoff $v$. Brown, ${ }^{64}$ and have suggested that it be provided that all causes of action could be joined that arose out of the same "subject of action." It might then have been suggested that all members of the bar would not agree as to the meaning of a subject of action, due to an inability to grasp the deeper significance of the equity rules. A combination of the two concepts might well have been regarded a compromise which would accomplish the general result of administrative convenience. An attempt to mark the boundary lines between a transaction and a subject of action by the consulting of dictionaries and looking to sentence structure seems to me to be futile. Each is an elastic concept, and there is no practical value in seeking the boundaries between them. The important point is that in combination they represent a rule of administration founded upon equity principles.

However elastic the rule as to joinder, there must be something to be joined, and it is not essential. and may be dangerous, to have the entities to be joined themselves elastic. The rule enacted in Connecticut and New Jersey seems to be more in the interest of literary style in story telling than service in the trial of law suits. It is difficult to see any practical advantage to be obtained in having a separate statement of the kind there provided for, since facts are not grouped according to the legal principles applicable to them in any part of the pleading.

able to them in any part of the pleading.

A New York case ${ }^{65}$ illustrates the practical difficulties encountered in stretching the cause of action to cover an entire event without regard

\footnotetext{
Supra note 26.

${ }^{\text {es Hahl v. Sugo, supra note } 3 .}$
} 
to legal principles or remedies. Plaintiff and defendant owned adjoining parcels of land, the boundary not being clearly defined. Defendant built on her parcel, the foundations of her building extending thirteen inches over the boundary. Plaintiff brought an action to obtain possession of the thirteen inch strip, and had judgment. Defendant paid the costs and took a new trial, as provided by a code section, following the ancient practice in ejectment. On the second trial plaintiff again had judgment establishing title in him, and awarding him the possession. It also contained a provision directing defendant forthwith to remove from the premises all obstructions put thereon by her. On motion of defendant the latter part of the judgment was stricken out. Execution was put in the hands of the sheriff, who made the return that it was impractical for him to execute it. Plaintiff then, in the same action, moved for an order requiring defendant to remove the obstruction, but this was denied. He then brought an action setting out the above facts, and asked for a mandatory injunction requiring defendant to remove the obstruction. In refusing this relief the Court of Appeals did not deny that plaintiff was entitled to the relief sought, but after stating and adopting Mr. Pomeroy's definition of a cause of action based on primary rights without regard to remedies, held that plaintiff had only one primary right in his land, and that defendant had committed but one delict in putting the obstruction on it, hence plaintiff had but one cause of action which could not be split into two suits. In holding that the judgment in the first suit exhausted plaintiff's remedies the court felt impelled to remark:

"but in view of the hardships visited upon the plaintiffs by the palpable and continuing wrong of the defendant, the reversal should be without costs."

That concluding remark condemns the entire decision. If there is a continuing wrong there still must be something to be wronged in the nature of a right. The one right and one delict both seem to have a continuing character, but a court having equity powers meekly bows before a rule of procedure that a single cause of action cannot be split, and confesses its lack of power to right an existing palpable wrong, and this despite the fact that the splitting of the cause of action was occasioned by defendant's motion. to sever! If this case is sound in principle all supplementary remedies in aid of judgments have been abolished, since it should be foreseen that a defendant will be contumacious, and the relief asked in the first suit. When a judgment creditor brings a creditor's action to discover assets and set aside fraudulent conveyances he splits his one cause of action, for he has but one right to his money and defendant has committed but one delict in keeping it from him. The illustration just suggested shows the fallacy of considering a cause of action as something apart from remedies. The court's decision was preposterous, but a natural result 
of accepting the definition of a cause of action based on unlimited primary, rights and delicts, or upon the simple and natural story of one event disassociated from the idea that the story is to be one of the necessary steps taken to obtain a desired result.

This same court, without change in its personnel, within two months held ${ }^{66}$ that when a defendant negligently left a gravel heap in a highway causing injury to plaintiff's person and vehicle by reason of running on to it, plaintiff might proceed in separate actions to redress the wrongs to his two several rights. In this case the court pointed out that it found two rights instead of one because one group of legal principles attached to person and a different group to property, different statutes of limitation applied, and the rules as to survivorship, assignment, and attachment by creditors were different. The court cited Brunsden v. Humphrey ${ }^{67}$ with approval, which case rests upon the quoted statement of Grose, J.:

"The question is not whether the sum demanded might have been litigated and considered in the former action, the only inquiry is whether the same cause of action has been litigated and considered in the former action."

That case also shows that the rule against splitting is founded upon the maxim "interest republicae ut sit finis litum" to prevent great oppression under color and pretense of law. Where oppression does not exist the rule is not to be applied, and, of course, it is not to be made an instrument of oppression.

It is strange that the same court within so short a time, and without apparently noticing it, should announce two such conflicting concepts as to a cause of action. In the one the simple story of the event, the transaction of putting the obstruction on land owned by plaintiff, without reference to remedial action, was adopted. In the other the principle contended for in this article, that a cause of action is a bundle of facts set apart by itself because of its relation to definite legal principles designed to produce a result through the courts, found its expression. ${ }^{68}$ The first proceeded upon the principle that what may be litigated in one suit must be litigated in that fashion, the second on the theory there may be optional joinders and severances within reasonable limits. The one was inelastic, and produced oppression. The

${ }^{60}$ Reilly v. Sicillian Asphalt Paving Co. (1902) I70 N. Y. 40, 62 N. E. 772. For a good discussion of this and related cases, see Wilson, Writs v. Rights (I9I9) I8 Mich. L. ReV. 255.

${ }^{\text {er }}$ (I88I) I4 Q. B. I4I.

${ }^{*}$ For a group of interesting cases where remedies have shaped the scope of rights, see Brozen v. Richter (1898, Ist Dept) 25 App. Div. 239, 49 N. Y. Supp. 368; Young v. Bradley (1879) xоI U. S. 782, 787; Doe v. Considine (I867, U. S.) 6 Wall. 458, 47x; Bogert, Trusts (I92I) sec. 84; Jarman, Wills (6th ed. rgro) I83I-I838. 
other was elastic, and avoided it. We may be somewhat surprised to observe that the formal cause of action produced the elasticity.

We will not solve procedural or other difficulties by a wholesale denunciation of everything that is old. Progress is built upon experiences of the past. Changes to meet new conditions there must be, but every change is not a revolution. In interpreting the codes we are repeating the mistakes of. the past because we are too intolerant of the past to inquire into the differences between the good and the bad in old procedure. We assume that all was pedantry because there was some pedantry. Good sense is confined to the present age, and the present age is impatient of form in procedure. But some form is essential in all societal action, in law, in government, in good manners. By form the gentleman moves in good society, while without it the boor finds it difficult to make progress. It may be carried to excess, and our task is to find a happy medium. With the full realization and acknowledgment of the fact that it emanates from a system of procedure which is more or less unpopular, and that it has distinctly formal characteristics, I submit the cause of action herein described as a tool calculated to simplify modern procedure and to make actions flexible without curtailing substantial rights. 